\title{
Stateless Iraqi Kurdish children and adolescents' mental health: A Scoping Review
}

En Chi Chen ( $\square$ angelachen110@shaw.ca )

McMaster University

\section{Research}

Keywords: refugees, statelessness, mental health, children, adolescents, Middle East, conflict, war, Kurdistan

Posted Date: November 25th, 2020

DOl: https://doi.org/10.21203/rs.3.rs-113316/v1

License: (9) This work is licensed under a Creative Commons Attribution 4.0 International License. Read Full License 
Stateless Iraqi Kurdish children and adolescents'...

\title{
Stateless Iraqi Kurdish children and adolescents' mental health: A scoping review
}

\author{
Running title: Stateless Iraqi Kurdish children and adolescents’
}

\author{
Author \\ En Chi Chen, McMaster University, Global Health \\ angelachen110@shaw.ca \\ 751 Shawnee Drive SW \\ Calgary, AB T2Y 1V6
}


Stateless Iraqi Kurdish children and adolescents' ...

\begin{abstract}
Kurdistan is one of the largest stateless nations in the world. Due to its geographical location, straddled between four major nation-states often in conflict with one another, Kurds face a disproportional level of conflict. Research has shown that there are significant mental health consequences as a result of living in conflict zones. It is suspected that the experience of statelessness in Kurdistan differs from the experience of individuals in neighbouring states, regardless of similar conflicts (Iraq, Iran, Syria, and Turkey). This could be due to the compounding effects of a sense of 'not belonging', as well as having barriers to accessing mental healthcare as a stateless individual. The current paper seeks to highlight the present literature on the understanding of conflict-related mental health consequences specifically affecting Iraqi Kurdish children and adolescents and to outline gaps in knowledge through a scoping review.
\end{abstract}

Keywords: refugees, statelessness, mental health, children, adolescents, Middle East, conflict, war, Kurdistan 
Stateless Iraqi Kurdish children and adolescents'...

\section{Introduction}

While there have been numerous studies on the topics of war and conflict, children, and mental health, some of which focus on regions in the Middle East, there appears to be an absence of studies which exist in the intersection of these topics, specifically for the stateless Kurdish children of Iraq. This specific population has experienced a disproportionate level of conflict in the recent two decades, beginning with the Iraq war in 2003 and ending with the war against the Islamic State of Iraq and Syria (ISIS) in the late 2010s. This is compounded by the wars that indirectly affect the Kurdish people, simply because of their geographical location. Currently, Kurdistan straddles the borders of four nations in the middle east: Iran, Iraq, Syria, and Turkey. Kurds are the second largest ethnicity in Iran, they make up 15\% of the Iraqi population, $10 \%$ of the population in Syria, and 19\% of the population of Turkey (BBC, 2019). Despite their significant presence in each country, only two of the four countries, Iran and Iraq, currently recognize the Kurdish region for its independence.

Among other challenges, Kurds face two significant challenges to self-determination. The first is that they are trying to exist as a non-state actor in a world that is dominated by nationstates. Membership in the United Nations is reserved to internationally recognized states; similarly, only sovereign entities can be Parties to treaties and other significant instruments of international law. This renders Kurds invisible in the most official political platforms and means that stateless peoples are the objects of actions of others and are not acting subjects in their own rights. Furthermore, they cannot meaningfully and legitimately participate in resolving issues on the agenda regardless of their relevance in the discussion. The second significant challenge is that Kurds live in a landlocked region dominated by four central governments, often with greater political and military power than that of Kurdistan. Because of its geographical location, the four 
Stateless Iraqi Kurdish children and adolescents'...

neighbouring countries have worked in tandem on various occasions to stifle resistance by Kurds in any one state. Consequently, the Kurds of greater Kurdistan are in a worse situation than many other stateless ethnic minorities around the world existing within the borders of a single nation.

When considering the history of Kurdistan, a broader lens needs to be applied which looks at the history of the Middle East as a whole and the conflicts that stem from international relations with superpowers in the Global North, chiefly the United States of America. In Faath \& Mattes' (2014) paper on migration from the Middle East and North Africa (MENA) countries to Europe, they highlight four unique forms of conflict that are relevant to the MENA as a result of the Cold War after the 1950s:

“1. Attempts to reinstate one's sovereignty over national territory or to reclaim such territory

2. Conflicts arising because of imprecise or disputed border demarcation stemming from colonial times

3. Conflicts concerning maritime borders or the exact course of borders for the purpose of offshore utilization, in particular in the Mediterranean Sea

4. Conflicts arising because of shortages of natural resources such as water or soil" (Faath \& Mattes, 2014, p. 164-166).

Apart from one of these reasons, due to Greater Kurdistan being landlocked within four nations and not having any maritime borders, all of the other reasons for conflict render Kurds acutely vulnerable to the consequences of war as a stateless nation with unestablished borders and a lack of central governance. Of the four regions within Greater Kurdistan, the fall of Saddam Hussein in 2003 allowed for Iraqi Kurds to become more autonomous in Northern Iraq. Kurds currently make 
Stateless Iraqi Kurdish children and adolescents'...

up an estimated $15 \%$ to $20 \%$ of Iraq's population (BBC, 2019). In 1946, Mustafa Barzani formed the Kurdistan Democratic Party (KDP) to fight for Kurdish autonomy in Iraq. "In the late 1970s... Iraqi[s] began settling Arabs in areas with Kurdish majorities, particularly around the oil-rich city of Kirkuk and forcibly relocating Kurds" (BBC, 2019). In 1980, during the Iran-Iraq War, the Kurds supported the Islamic republic. In 1988, Saddam Hussein unleashed a campaign of vengeance on the Kurds and attempted to destroy Kurdish resistance by depopulating the region systematically (Montgomery, 1998). This resulted in the horrific event known as the Halabja Massacre whereby a chemical attack was carried out against the Kurdish people. This attack killed between 3,200 to 5,000 people and injured nearly 10,000 more, most of whom were innocent civilians (The Times, 2010). This also resulted in half a million Kurds being displaced (Montgomery, 1998). This chemical warfare disproportionally affected pregnant women and unborn children who showed an increase in birth defects years after the incident (Hilmas, E., \& Hilmas, C. J., 2015). When Iraq was defeated in the 1991 Gulf War, Barzani's son Massoud and Jalal Talabani of the rival Patriotic Union of Kurdistan (PUK) led a Kurdish rebellion (BBC, 2019). The U.S. and its allies imposed a no-fly zone in Northern Iraq at this time and this propelled the two political parties, the KDP and the PUK, to begin negotiations around sharing power within the Iraqi Kurdish region (BBC, 2019). This did not last long and tension began to rise which resulted in a four-year civil war from 1994 and 1998.

In 2003, the U.S. led the invasion and began the Iraq war to overpower Saddam Hussein's regime. The two parties cooperated with the U.S., and after the "success" of the war (i.e. the liberation of the people of Iraq from the dictatorial leader Hussein), KDP and PUK began governing Iraqi Kurdistan in conjunction with the Kurdistan Regional Government (KRG). In September 2017, a referendum on independence was held in both the Kurdistan Region and the 
Stateless Iraqi Kurdish children and adolescents'...

disputed areas seized by the Peshmerga in 2014, including Kirkuk (BBC, 2019). The vote was opposed by the Iraqi central government (BBC, 2019). More than $90 \%$ of the 3.3 million people who voted supported secession. The loss of Kirkuk and its oil revenue was economically detrimental for Iraqi Kurds. Following this event and the resignation of the president there was a period of time in which there was no regional governance, leading to unrest amongst the people.

To add to the already unstable political climate in the Middle East, ISIS posed another threat to the wellbeing of the Kurdish people. In mid-2013, the jihadist group of the Islamic State (IS) turned its sights on three Kurdish enclaves that bordered territory under its control in Northern Syria. An IS advance in northern Iraq in June 2014 also drew Iraqi Kurds into conflict. In August 2014, the IS group launched a surprise offensive and the Peshmerga (the forces sent in by the Iraqi government to the Kurdish region) withdrew from several areas (BBC, 2019). Most notably, one of the areas was Sinjar where IS militants killed or captured thousands of Yazidis, a prominent religious minority of Iraqi Kurds. This caused the internal displacement of thousands.

Several key events occurred that resulted in the Syrian Democratic Forces (SDF) declaring the total elimination of ISIS in March of 2019. One such event was driving out ISIS troops from Kobane, Syria in 2015 and another was capturing the IS capital Raqqa and the neighbouring province of Deir Al-Zour which was believed to be the last IS invaded territory in Syria in 2017 (BBC, 2019). However, this is not the end of Middle Eastern conflict against ISIS as there is potential for the "jihadist" sleeper cells to regain power and to ignite the second rise of ISIS (Farooqi, Azhar, \& Tashfeen, 2018).

The most recent threat to the safety of the Kurdish people happened in October 2019 when the U.S. troops pulled back from the border with Turkey after President Trump said it was about to launch an operation to set up a 32km deep "Safe-zone" to resettle up to two million Syrian 
Stateless Iraqi Kurdish children and adolescents'...

refugees. Turkish troops and allied Syrian rebels immediately advanced into the unguarded lands in an offensive that displaced over 300,000 Syrian Kurds (UN News, 2019). These recent events emphasize the continuing struggle against conflicts in Kurdistan and how international, external forces and decisions can have detrimental effects on the Kurdish people.

Studies that have focused on this region have either neglected to recognize the unique identity as a stateless individual, which should not be undermined as they are not privy to any of the benefits that come from being a citizen of a state that is recognized by international institutions. The Kurdish children of the last two decades have existed in the unique intersection of various vulnerabilities which cannot be understood independently from one another. For the purpose of this review, children will be defined as individuals under the age of 18 , based on the definition set out by the United Nations Convention of the Rights of the Child. This study addresses a unique population which has historically been neglected in research or bundled with other groups, such as refugees or internally displaced individuals. A summation of the existing literature surrounding this topic will better inform the direction of future research in the everchanging political climate that is the Kurdistan region. 
Stateless Iraqi Kurdish children and adolescents'...

\section{Method}

A search was undertaken on April 18, 2020 using the following databases after a consultation with a McMaster University's Librarian: JSTOR, Political Science Database, PsychINFO, Scholar Portal Journal, Scopus, Web of Science - All Data Base, and Wiley Online Library. These databases were chosen to include the multidisciplinary nature of the research question.

Keywords search for JSTOR, Political Science Database, and PsycINFO:

1. Refugee OR stateless

2. Mental health

3. Child* OR youth* OR adolescent*

4. Middle east OR conflict or war OR Kurdistan

Keywords search for Scopus:

1. Refugee OR displaced OR conflict

2. Mental health

3. Child* OR youth* OR adolescent*

4. Middle east OR Kurdistan

Keywords search for Web of Science and Wiley Online Library:

1. Refugee OR displaced OR conflict

2. Mental health

3. Child* OR youth* OR adolescent*

4. Middle east OR Kurdistan

Only peer reviewed articles published on or after the year 2000 were considered. This initial search result identified 409 papers. Titles were screened for relevance to research topic. 
Stateless Iraqi Kurdish children and adolescents'...

Those that did not fit the criteria of investigating the relationship between displaced individuals and mental health specifically in the Middle East were excluded. Those that included populations that have been resettled in a Global North country were also excluded. This resulted in only 10 eligible papers for review. None of these papers fit the criteria exactly, as outlined in the results table. 
Stateless Iraqi Kurdish children and adolescents'...

\section{Results}

The results of the studies revealed that to date, no study has been done specifically on stateless Iraqi Kurdish children's mental health. To support the importance of pushing forward this research agenda to better understand the unique lived experiences of that specific population, ten papers will be analyzed. Although these papers do not completely align with the interests of the research question, there are components in each which shed light on the current research question such as similar population of interests (refugee, children, or internally displaced individuals) or within similar geographical regions (within the Middle East). 
Table 2: Elements within and outside of research question criteria for all included papers.

Title

Disputed Territory

and Ethno-religious

Diversity: An

Opportunity for the

Development of

Iraq's National

Policy on

Displacement

Refugee children

from the middle east

Trauma, Exile and
Mental Health in
Young Refugees
Discrimination,
mental problems and
social adaptation in
young refugees

young refugees

The impact of

military deployment

on children: placing

developmental risk

in context
Authors, Publication

(Louise, 2019)

(Montgomery, 1998)

Rehabilitation and Research Centre for

Torture Victims, Copenhagen,

Medicine, Aarhus University

(Montgomery, 2011)

Acta Psychiatrica Scandinavica

\section{Journal Elements within research question criteria}

\author{
Middle East Research Institute
}

\section{(Montgomery \& Foldspang,}

2008)

European Journal of Public Health
Department of Epidemiology and Social
(Alfano et al., 2016)

Clinical Psychology Review
Mental health of

children in the

Middle East who

have experienced

prolonged war or

organized violence

Mental health of

children who have

experienced trauma

in the Middle East

(n)

Mental health as a result of perceived discrimination among children from the Middle East Developmental risk of children in the Middle East due to conflict
Focused on

internally

displaced

individuals and

not stateless

Kurdish

individuals

Focuses on

refugee children

who have spent

significant time

in refugee camps

Focused on exile

related

individuals who

have been forced

out of their home

countries

Focused on

refugees who

have since left

the Middle East

Focused on military deployed children who have been in more direct contact with conflict 


\begin{tabular}{|c|c|c|c|c|}
\hline $\begin{array}{l}\text { Mitigating the } \\
\text { Impact of Forced } \\
\text { Displacement and } \\
\text { Refugee and } \\
\text { Unauthorized Status } \\
\text { on youth: Integrating } \\
\text { Developmental } \\
\text { Processes with } \\
\text { Intervention } \\
\text { Research }\end{array}$ & (Yoshikawa et al., 2019) & $\begin{array}{l}\text { Humanitarianism and Mass Migration: } \\
\text { Confronting the World Crisis }\end{array}$ & $\begin{array}{l}\text { Developmental } \\
\text { processes and } \\
\text { mental health of } \\
\text { youth as a result of } \\
\text { forced displacement }\end{array}$ & $\begin{array}{l}\text { Coagulated } \\
\text { refugees and } \\
\text { unauthorized } \\
\text { (stateless) } \\
\text { individuals rather } \\
\text { than recognizing } \\
\text { the difference } \\
\text { between the two } \\
\text { people groups }\end{array}$ \\
\hline $\begin{array}{l}\text { Annual Research } \\
\text { Review: Resilience } \\
\text { and mental health in } \\
\text { children and } \\
\text { adolescents living in } \\
\text { areas of armed } \\
\text { conflict - a } \\
\text { systematic review of } \\
\text { findings in low- and } \\
\text { middle-income } \\
\text { countries }\end{array}$ & (Tol et al., 2013) & $\begin{array}{l}\text { Journal of Child Psychology and } \\
\text { Psychiatry and Allied Disciplines }\end{array}$ & $\begin{array}{l}\text { Resilience and } \\
\text { mental health of } \\
\text { children and } \\
\text { adolescents in } \\
\text { armed conflict } \\
\text { zones }\end{array}$ & $\begin{array}{l}\text { General focus on } \\
\text { low- and middle- } \\
\text { income countries } \\
\text { that are not } \\
\text { specific to Iraqi } \\
\text { Kurdistan's } \\
\text { stateless children }\end{array}$ \\
\hline $\begin{array}{l}\text { Health needs and } \\
\text { care seeking } \\
\text { behaviours of } \\
\text { Yazidis and other } \\
\text { minority groups } \\
\text { displaced by ISIS } \\
\text { into the Kurdistan } \\
\text { region of Iraq }\end{array}$ & (Cetorelli et al., 2017) & PloS one & $\begin{array}{l}\text { Focused on the } \\
\text { specific } \\
\text { displacement due to } \\
\text { ISIS in Iraq and the } \\
\text { Yazidi minority }\end{array}$ & $\begin{array}{l}\text { Not specific to } \\
\text { children and } \\
\text { adolescents and } \\
\text { is a general } \\
\text { overview of } \\
\text { health needs } \\
\text { rather than a } \\
\text { focus on mental } \\
\text { health }\end{array}$ \\
\hline $\begin{array}{l}\text { Trauma and } \\
\text { perceived social } \\
\text { rejection among } \\
\text { Yazidi women and } \\
\text { girls who survived }\end{array}$ & (Ibrahim et al., 2018) & BMC Medicine & $\begin{array}{l}\text { Focused on the } \\
\text { traumatic } \\
\text { experience of } \\
\text { enslavement and } \\
\text { genocide on Yazidi } \\
\text { individuals and the }\end{array}$ & $\begin{array}{l}\text { Focused } \\
\text { specifically on } \\
\text { women and girls } \\
\text { rather than } \\
\text { children (both } \\
\text { boys and girls) }\end{array}$ \\
\hline
\end{tabular}


Stateless Iraqi Kurdish children and adolescents'...

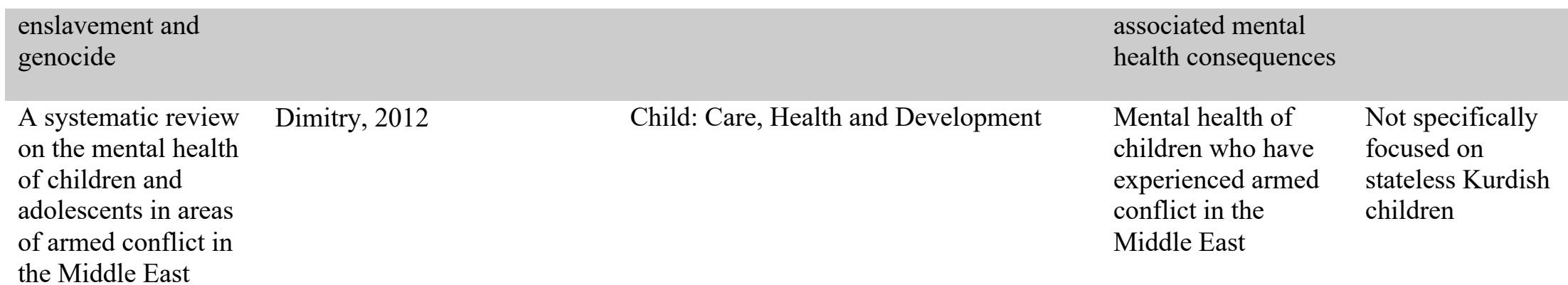


Stateless Iraqi Kurdish children and adolescents'...

\section{Summary of each paper's findings}

The policy paper "Islamic State, Disputed Territory and Ethno-religious Diversity: An Opportunity for the Development of Iraq's National Policy on Displacement" (Louise, 2019) identified protection gaps within Iraq's response to displacement. The legacy and persisting existence of the Islamic State (IS) in Iraq significantly exacerbates an already challenging displacement context. Further complicating the situation is the conflict between the Government of Iraq (GoI) and the Kurdistan Regional Government (KRG) over the resource-rich "Disputed Territories". How the GoI and KRG respond to internally displaced populations (IDPs) who are perceived as IS-affiliates will have far-reaching, generational consequences. The most pressing concerns for these displaced groups are forced, premature, uniformed and obstructed returns, lack of civil documentation, severe movement restrictions in camps, and arbitrary detention. All of these challenges lead to dire consequences for the mental health of displaced populations. Perceived IS-affiliates are at great risk of torture whilst detained, reporting experiences of or witnessing "electrical shocks, being hung by arms and feet, showered with boiling water, and deprived of meals" (Louise, 2019, p. 7). Additionally, due to institutional shortcomings, there is the potential for detained IDPs to fall through administrative cracks, without legal documentation and no rights in the eyes of internationally established institutions. This paper argues that perceived IS affiliates must all be offered the same protection as minorities and other vulnerable groups of IDPs.

"Refugee children from the middle east" by Montgomery (1998) mapped the prevalence of torture victims among parents in asylum seeking refugee families in the Middle East, experiences of war and other forms of organized violence among the children of these families, and the emotional symptoms and behavioural problems among the children. The findings suggest 
Stateless Iraqi Kurdish children and adolescents'...

that the most important risk indicators for anxiety were living in a refugee camp outside the home country, being a part of a torture surviving family, the lack of opportunities to engage with social play with other children, being physically abused by officials, or experiencing the loss of a father figure. They also found that living under prolonged conditions influenced by war and other forms of organized violence were associated with a higher degree of risk than specific life events of changes in life condition.

In “Trauma, Exile and Mental Health in Young Refugees”, Montgomery (2011) reviewed evidence of trauma and exile-related mental health in young refugees from the Middle East and concluded that psychological problems are frequent amongst refugee children, but the extents are reduced over time in exile. The children's traumatic background only limitedly determined the long-term mental health of that individual while exile-related stressors, such as experienced discrimination, had a stronger correlation with poor mental health.

In "Discrimination, mental problems and social adaptation in young refugees", Montgomery \& Foldspang (2008) showed that perceived discrimination among young refugees from the Middle East is associated with mental illnesses and social adaptation difficulties. There is not a directive relationship, rather it is many recursive interactions between mental health, discrimination, and social adaptation. This is the figure representing those relationships:

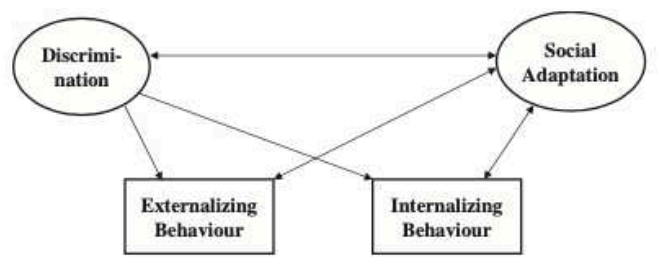

Figure 2. Relationship between discrimination, externalizing behaviour, internalizing behaviour, and social adaptation as described by Montgomery \& Foldspang (2008) "Discrimination, mental problems and social adaptation in young refugees" (p. 157). 
Stateless Iraqi Kurdish children and adolescents'...

"The impact of military deployment on children: placing developmental risk in context" is one of the only studies that specifically focuses on the unique experience of children, even going as far as to consider children by age group: toddlers, preschoolers, school age children, and adolescents (Alfano et al., 2016). This study specifically focused on deployment of children as child soldiers and those children who have engaged in military acts either directly or indirectly through being part of a family who has been deployed.

In the paper "Mitigating the Impact of Forced Displacement and Refugee and Unauthorized Status on youth: Integrating Developmental Processes with Intervention Research", Yoshikawa et al. (2019) argues that different statuses short of formal asylum or temporary or permanent citizenship lead to exclusion from developmental support for children and adolescents. Aside from general disruptions to the lives of refugee children, educational processes are also threatened and interrupted. Risk factors are defined as anything that amplifies the probability of a negative outcome whereas protective factors are anything that lower the probability of a negative outcome, given exposure to adversity. Recognizing the impact of natural, biological factors, at the centre of the model that the author developed (Figure 3), is the less malleable, "predetermined" characteristics that impact how an individual might respond to a situation. Studies have linked childhood maltreatment-related posttraumatic stress disorder to differences in volume of the hippocampus and amygdala — areas of the brain involved in emotional regulation and cognitive processing. Furthermore, childhood stress and trauma have been linked to faster shortening of telomeres which is reflective of one's age and is often associated with the development of diseases such as cancer. 
Stateless Iraqi Kurdish children and adolescents' ...

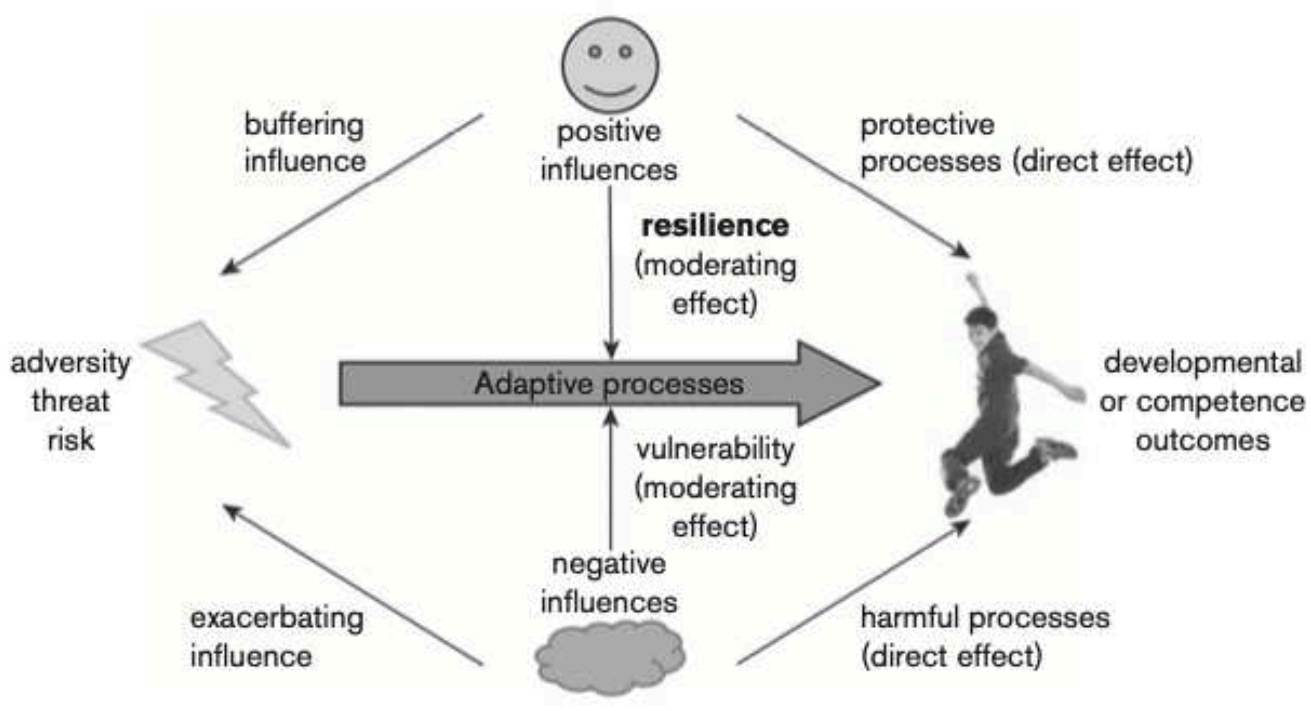

Figure 3. Model representing the adaptive process based on the study "Mitigating the Impact of Forced Displacement and Refugee and Unauthorized Status on youth: Integrating Developmental Processes with Intervention Research" by Yoshikawa et al. (2019, p. 189).

Yoshikawa et al.'s paper categorized events as either "risk factors and processes" which have an overall negative impact on the displaced child's development or "protective and promotive factors in the face of adversity" which have an overall positive impact on the displaced child's development. A few risk factors include the degree of exposure to conflict which is directly correlated to depression and other self-regulatory challenges. In addition, the degree to which the individual was involved in or engaged with the war affects their mental health consequences. Parent or caregiver stress, anxiety, or depression have been shown to predict the elevated internalized symptoms of their child or youth. The timing and duration of exposure to these contextual stressors can also affect developmental outcomes. For example, enduring chronic levels of stress for an extended period of time can have long term implications on health, development, and future mental health. Finally, there is convincing evidence that cumulative risk or prolonged multiple risks can affect the severity to which an individuals' mental health is affected; specifically, there is risk of increased mental illness severity for those 
Stateless Iraqi Kurdish children and adolescents'...

who experience risk factors in early childhood rather than later in adolescence. Protective factors that impact a child or adolescents' ability to cope with migrative trauma include that of social support from peers, social inclusion, and community acceptance. Furthermore, for older adolescence, economic and employment opportunities are linked to positive outcomes and better mental health.

In the "Annual Research Review: Resilience and mental health in children and adolescents living in areas of armed conflict - a systematic review of findings in low- and middle-income countries", it was concluded that resilience is a complex dynamic, driven by time- and context-dependent variables, rather than the balance between risk- and protectivefactors with known impacts on mental health (Tol et al., 2013). This confirms that studies must be specified to a population and experiences cannot be generalized among different groups. There is no universal model that may explain mental health across all contexts.

"Health needs and care seeking behaviours of Yazidis and other minority groups displaced by ISIS into the Kurdistan region of Iraq" Cetorelli et al. (2017), showed that the demand for health services was high among Yazidis and other minorities residing in camps. Declines in the public sector funding further restricted access to camp clinics, stressing the need for alternative access strategies for health care.

In "Trauma and perceived social rejection among Yazidi women and girls who survived enslavement and genocide", the participants reported a high number of traumatic events—more than $80 \%$ of girls and women and almost all participants who were formerly enslaved, met the criteria for post-traumatic stress disorder (PTSD) diagnosis (Ibrahim et al., 2018). Furthermore, perceived social rejection in their community mediated the relationship between traumatic enslavement and depressive symptoms. 
Stateless Iraqi Kurdish children and adolescents'...

Finally, "A systematic review on the mental health of children and adolescents in areas of armed conflict in the Middle East" is the first paper of its kind to systematically review the literature on mental health of children living in areas of armed conflict in the Middle East including Iraq (Dimitry, 2012). The main findings are that children and adolescents living in these conflict zones are exposed to high levels of traumatic experiences and experience a prevalence of PTSD. Some of the main determining factors identified were levels and types of exposure, age, gender, socio-economic adversity, social support, and religiosity.

Summary, analysis and models

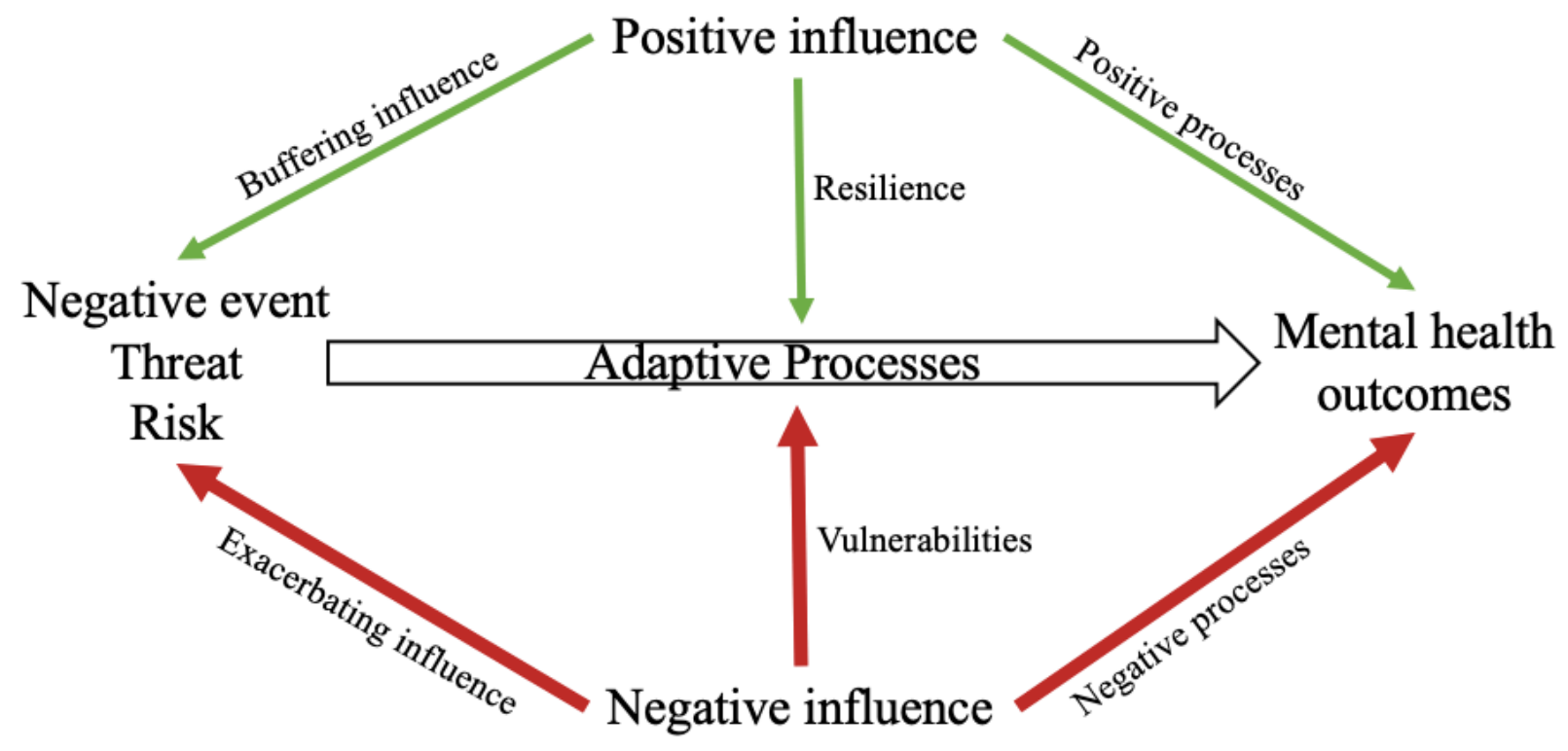

Figure 4. Model based on Figure 3, adapted to include mental health outcomes and highlighting the negative vs. positive influences on the adaptive process with red vs. green arrows, respectively. 


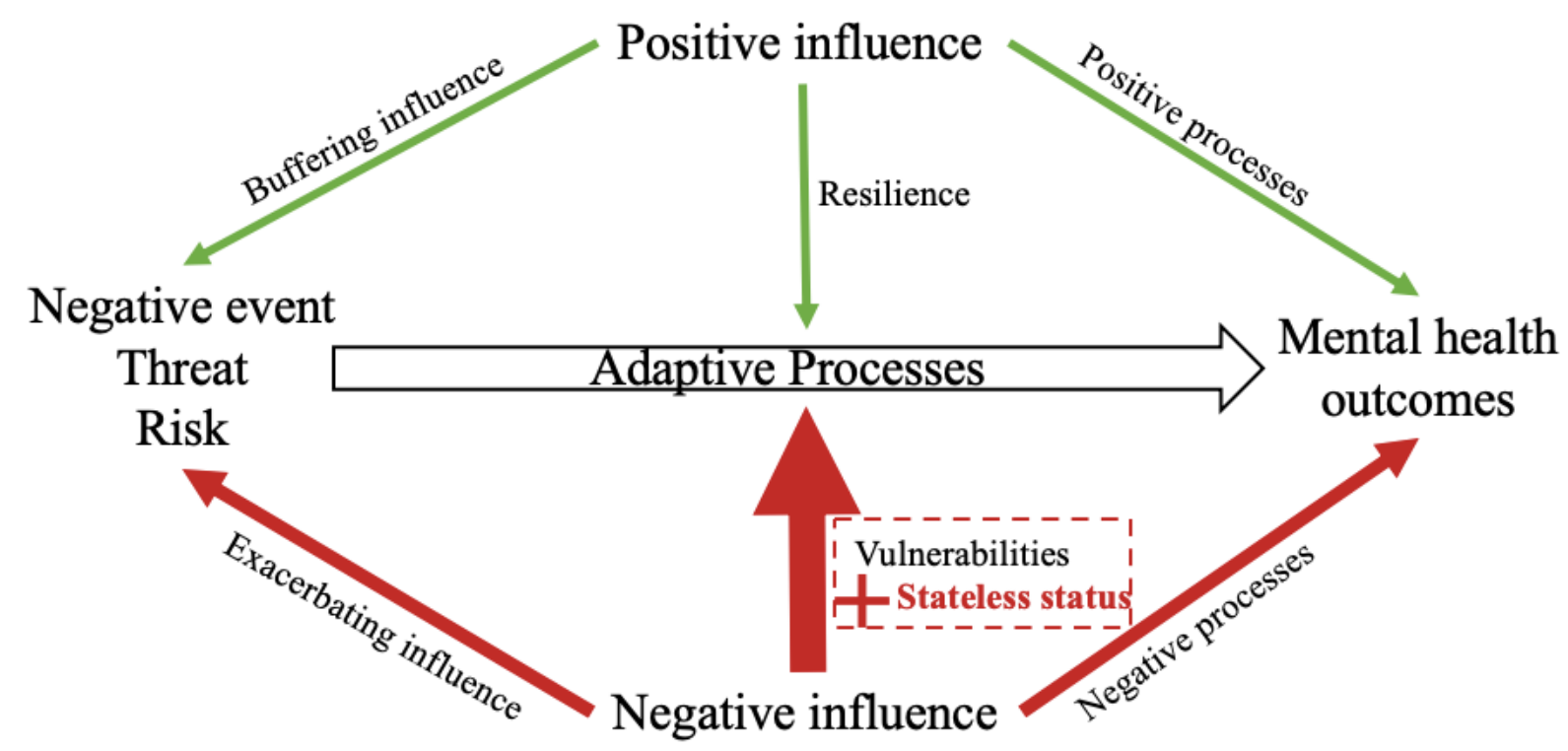

Figure 5. Model based on Figure 4, adapted to include the additional vulnerability of statelessness that causes a disproportional negative influence on the adaptive process and thus affects the resulting mental health outcome. The size of the arrow is reflective of its disproportional affect. 
Stateless Iraqi Kurdish children and adolescents'...

\section{Discussion}

To date, there are no studies specifically focused on the lived experiences and consequential mental health of stateless Iraqi Kurdish children and adolescents. Though this population has existed for nearly a century, been through numerous tragedies, wars, and conflicts, and been the subject of discrimination, they have been neglected in the literature. When they are considered in research, they are categorized with other refugees or internally displaced people groups under the presumption that the vulnerabilities they face are similar enough to these other groups to equate to the same experience. These silences the voices of an already marginalized group within the Middle East and perpetuates a narrative that statelessness is not a specific vulnerability placing an individual at a disproportional disadvantage when it comes to achieving mental wellbeing. Thus, to garner a better understanding of this people group, specifically the children who have lived through the recent two decades of continued displacement and trauma related to the Iraq war and ISIS, a research agenda should be established to fill the gap in knowledge. Furthermore, this scoping review serves to highlight the inconsistency in the "types of people groups" researchers include in their studies under the general umbrella of "displaced individuals" without consideration for their specific status as being refugees, internally displaced individuals, stateless individuals, or asylum seekers. Under international institutions such as the United Nations High Commissioner for Refugees (UNHCR), each group experience their displacement, the associated human rights protections, and resettlement processes differently and should not be categorized as the same. The absence of studies done on this specific population of Iraqi Kurdish children is reflective of a global research agenda that does not recognize the importance of highlighting the unique lived experience of this people group. To meaningfully bring about positive change and better mental 
Stateless Iraqi Kurdish children and adolescents'...

health for Iraqi Kurdish children we must begin by first understanding their experiences and recognizing that the intersection of their identity as a stateless child may play a greater role in dictating their experiences and resulting mental health. Thus, to begin bridging the lack of understanding, a research agenda must be put in place. This would require international institutions such as the United Nations to recognize the importance of such research projects. Furthermore, it would require research groups to form meaningful partnerships with local civil society organizations who have worked amongst the people and cultivated a level of mutual trust with the communities. Because of the nature of such sensitive research and the relatively narrow understanding of mental health within the Global North, conducting research in this field will require adopting a posture of genuine humility. In collaboration with these civil society organizations, greater strides can be made to address the gaps in knowledge and garner a more holistic understanding of the lived experiences of Iraqi Kurdish, internally displaced children and adolescents. 
Stateless Iraqi Kurdish children and adolescents'...

\section{Abbreviation}

1. Gol: Government of Iraq

2. IDP: Internally displaced populations

3. ISIS/IS: Islamic State of Iraq and Syria/Islamic State

4. KDP: Kurdistan Democratic Party

5. KRG: Kurdistan Regional Government

6. MENA: Middle East and North Africa

7. PTSD: post-traumatic stress disorder

8. PUIC: Patriotic Union of Kurdistan

9. SDF: Syrian Democratic Forces

10. UNHCR: United Nations High Commissioner for Refugees 
Stateless Iraqi Kurdish children and adolescents'...

\section{Declarations}

\section{Ethics approval and consent to participate}

Not applicable.

Consent for publication

Not applicable.

Availability of data and materials

Not applicable.

Competing interests

Not applicable.

Funding

Not applicable.

Authors' contributions

EC contributed to the entire production of the paper.

\section{$\underline{\text { Acknowledgement }}$}

A special thank you to Dr. Marshall Beier who graciously supervised the writing of this paper from its conception to completion. Your insights into this topic were tremendously helpful and your edits, invaluable. Thank you for your guidance and your continued support. This paper was inspired by my work in Kurdistan, Iraq in 2019 with Preemptive Love Coalition, without which, the paper would lack context and passion.

Authors' information

En Chi Chen, MSc.

Current Program Officer at Dahdaleh Institute for Global Health Research 
Stateless Iraqi Kurdish children and adolescents'...

\section{Resources}

Alfano, C. A., Lau, S., Balderas, J., Bunnell, B. E., \& Beidel, D. C. (2016). The impact of military deployment on children: Placing developmental risk in context. Clinical Psychology Review, 43, 17-29. https://doi.org/10.1016/j.cpr.2015.11.003

Cetorelli, V., Burnham, G., \& Shabila, N. (2017). Health needs and care seeking behaviours of Yazidis and other minority groups displaced by ISIS into the Kurdistan Region of Iraq. PloS One, 12(8), e0181028. https://doi.org/10.1371/journal.pone.0181028

Dimitry, L. (2012). A systematic review on the mental health of children and adolescents in areas of armed conflict in the Middle East. Child: Care, Health and Development, 38(2), 153161. https://doi.org/10.1111/j.1365-2214.2011.01246.x

Faath, S., \& Mattes, H. (2014). 5.Political Conflicts And Migration In The Mena States. Migration from the Middle East and North Africa to Europe, 159-190. https://doi.org/10.1515/9789048523177-008

Ibrahim, H., Ertl, V., Catani, C., Ismail, A. A., \& Neuner, F. (2018). Trauma and perceived social rejection among Yazidi women and girls who survived enslavement and genocide. BMC Medicine, 16(1), 1-11. https://doi.org/10.1186/s12916-018-1140-5

Louise, S. (2019). Islamic State, Disputed Territory and Ethno-religious Diversity : An Opportunity for the Development of Iraq's National Policy on Displacement.

Montgomery, E. (1998). Refugee Children from the Middle East. Rehabilitation and Research Centre for Torture Victims, Copenhagen, Department of Epidemiology and Social Medicine, Aarhus University, 54(1), 1-152. https://doi.org/10.1177/0022343305049666

Montgomery, E. (2011). Trauma, Exile and Mental Health in Young Refugees. Acta Psychiatrica Scandinavica, 124(SUPPL. 440), 1-46. https://doi.org/10.1111/j.1600- 
Stateless Iraqi Kurdish children and adolescents'...

0447.2007.01074.x

Montgomery, E., \& Foldspang, A. (2008). Discrimination, mental problems and social adaptation in young refugees. European Journal of Public Health, 18(2), 156-161. https://doi.org/10.1093/eurpub/ckm073

Tol, W. A., Song, S., \& Jordans, M. J. D. (2013). Annual research review: Resilience and mental health in children and adolescents living in areas of armed conflict - A systematic review of findings in low- and middle-income countries. Journal of Child Psychology and Psychiatry and Allied Disciplines, 54(4), 445-460. https://doi.org/10.1111/jcpp.12053

Yoshikawa, H., Wuermli, A. J., \& Aber, J. L. (2019). Mitigating the Impact of Forced Displacement and Refugee and Unauthorized Status on Youth: Integrating Developmental Processes with Intervention Research. Humanitarianism and Mass Migration: Confronting the World Crisis, 186.

Word Count: 5059 
Figures
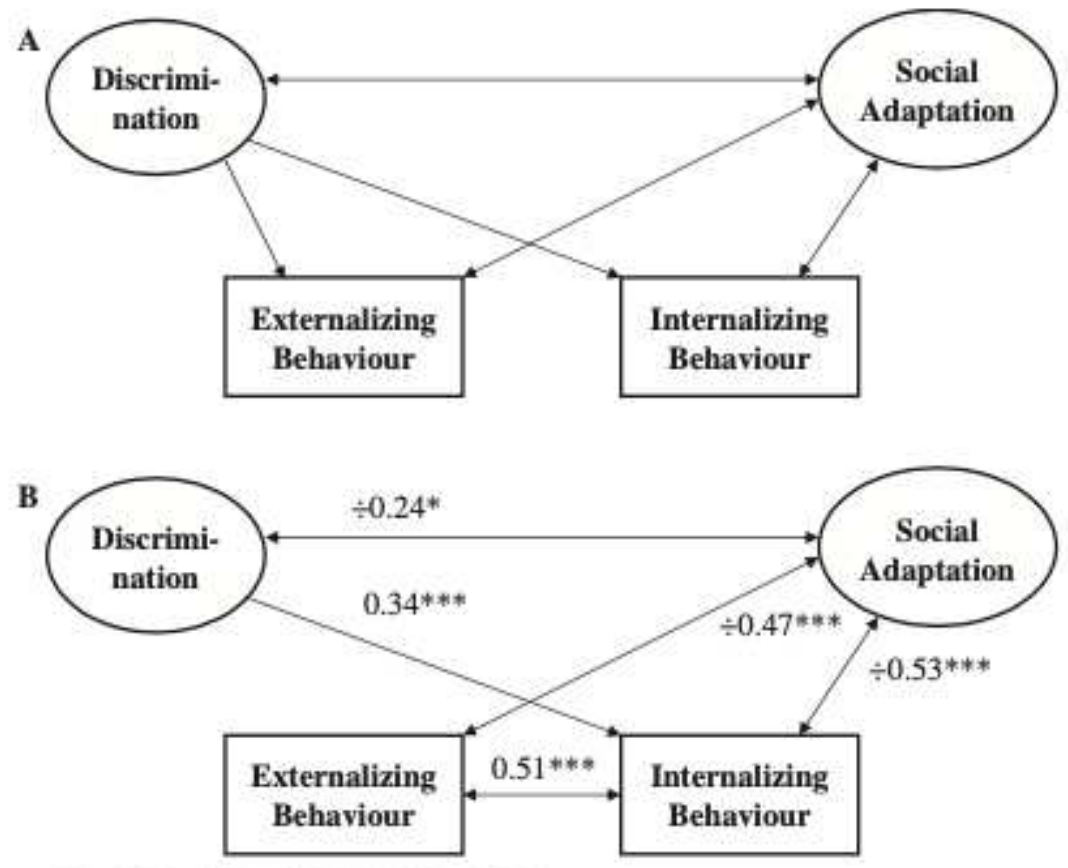

* $\mathrm{P}<0.05 ; * * \mathrm{P}<0.005 ; * * * \mathrm{P}<0.001$

\section{Figure 1}

Model for associations between discrimination mental problems and social adaptation. Ellipses represent latent variables, squares observed variables. (A) Theoretical model. (B) Empirical model with standardized parameter extimates, corrected for sex, age, nationality and ethnicity.

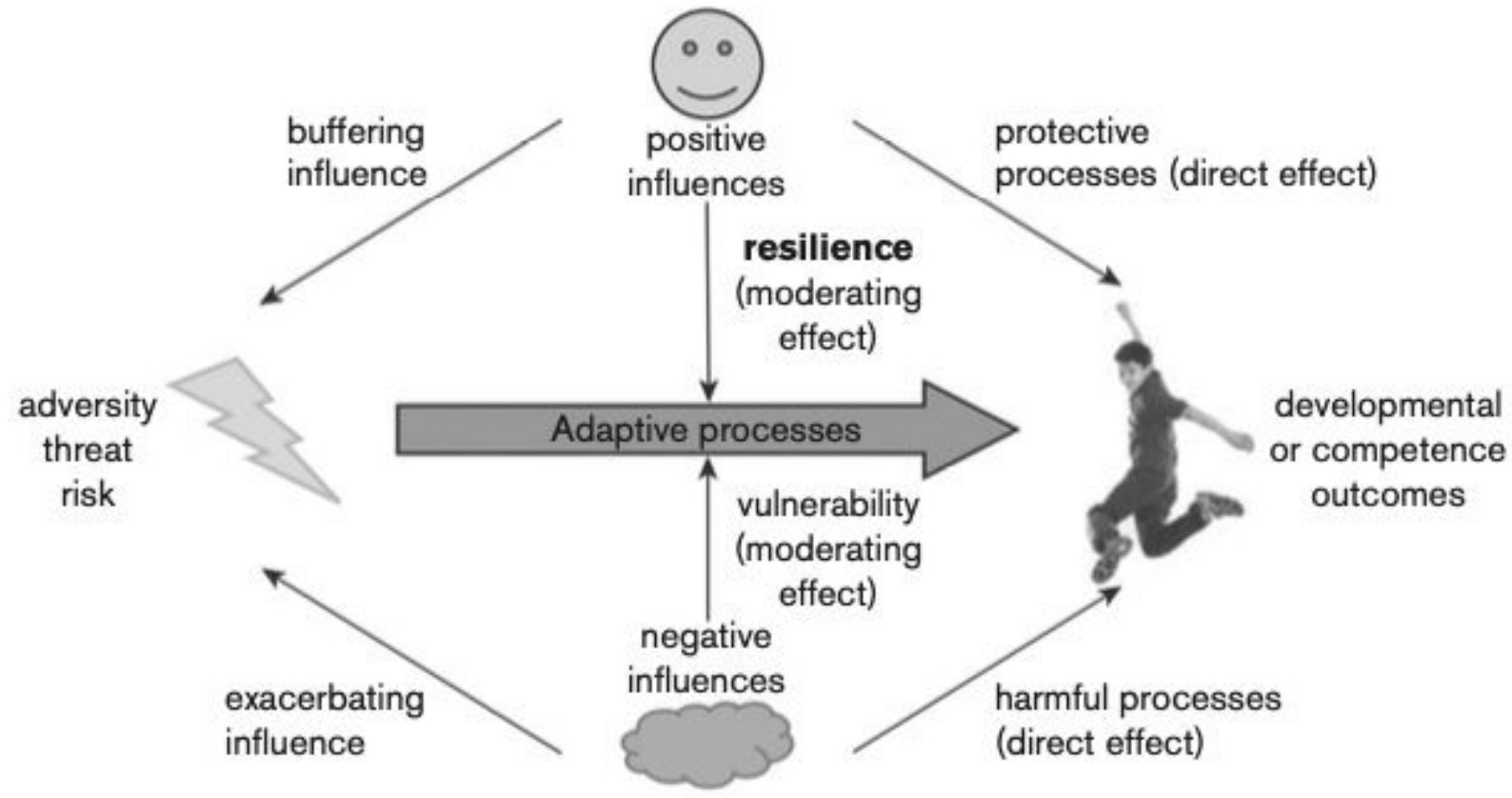

Figure 2 
Risk and resilience in adaptive processes in the face of adversity. Source: Adapted from figure 2.3. "Distinction between Resilience and Risk Reduction and Protection", in Aber (2012).

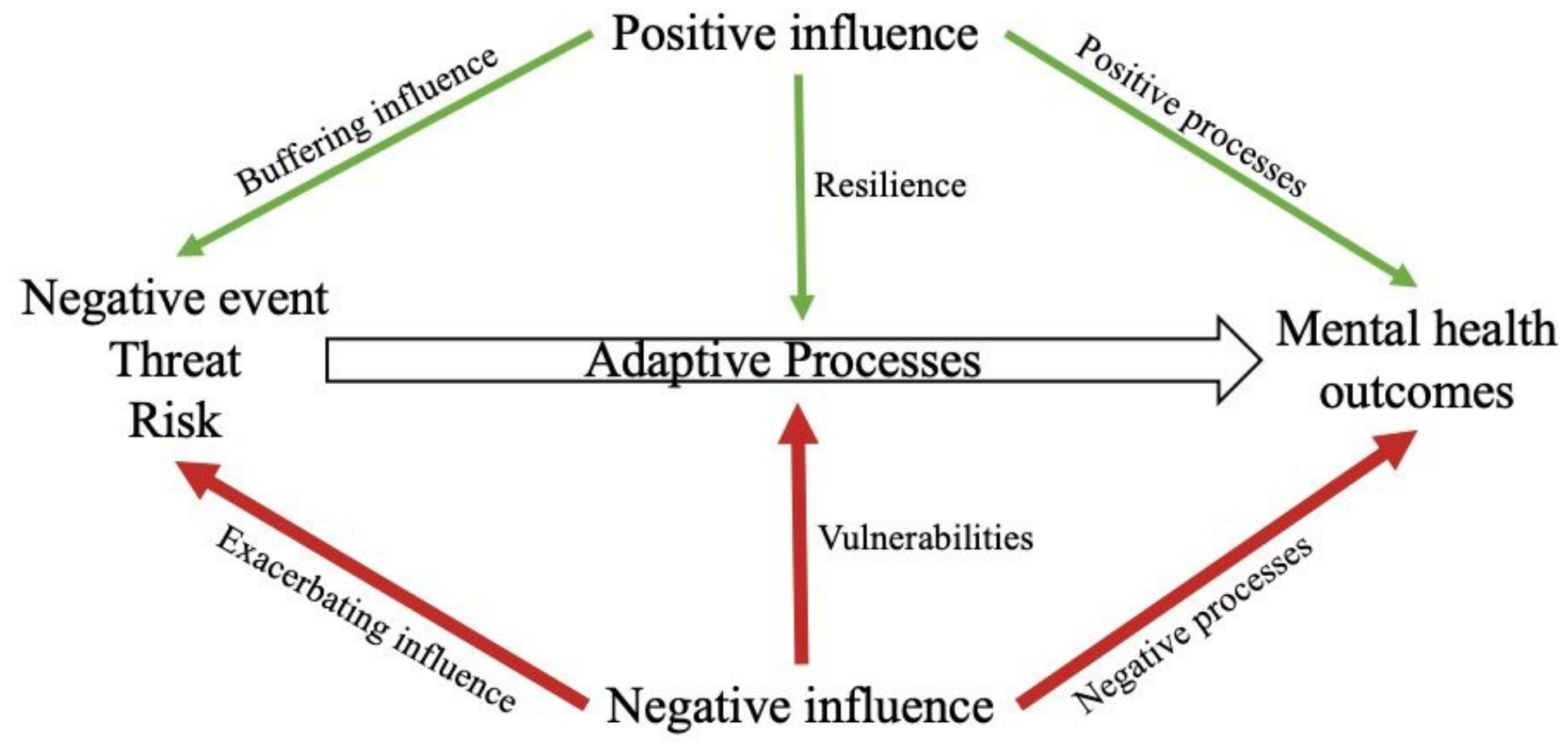

Figure 3

Model based on Figure 3, adapted to include mental health outcomes and highlighting the negative vs. positive influences on the adaptive process with red vs. green arrows, respectively.

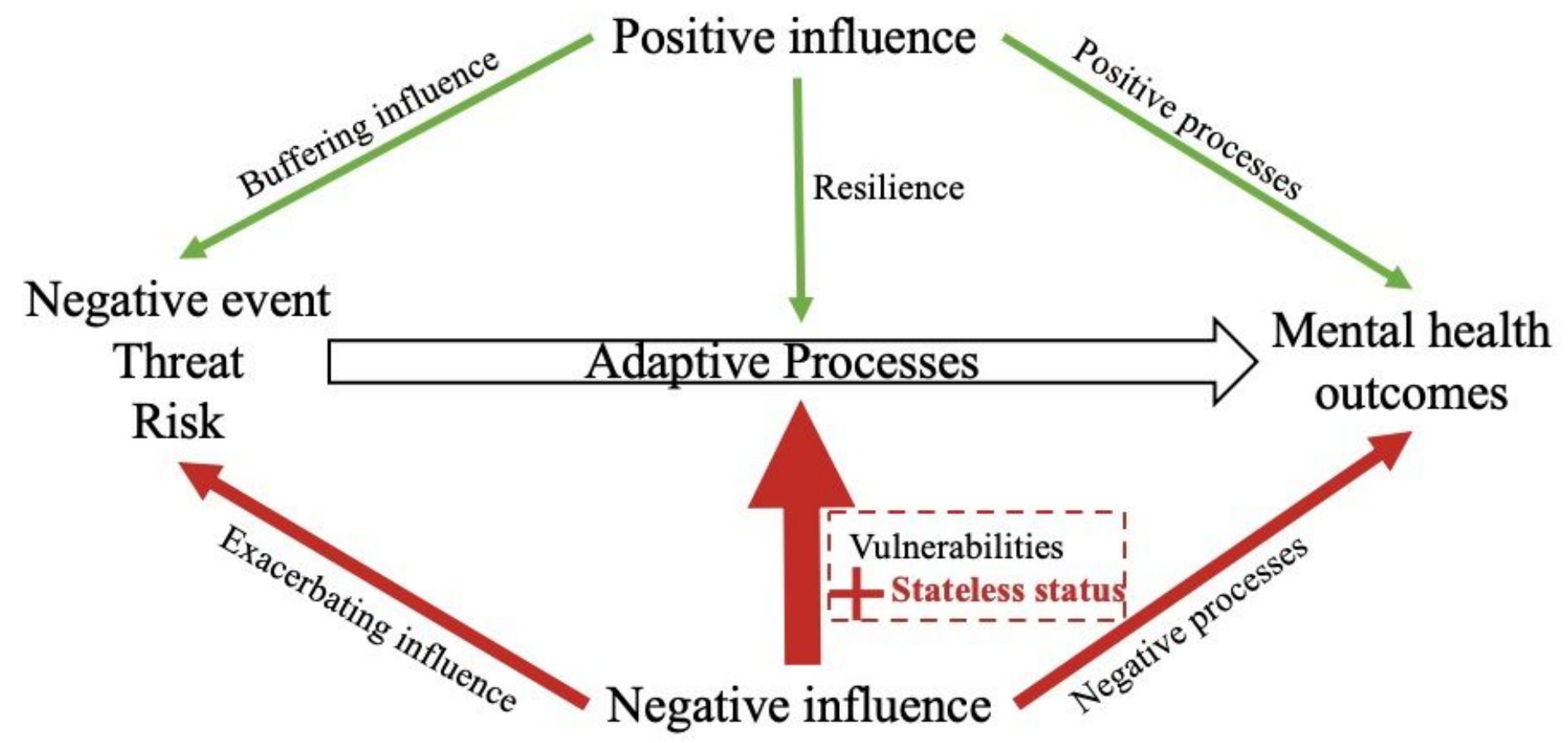

Figure 4 
Model based on Figure 4, adapted to include the additional vulnerability of statelessness that causes a disproportional negative influence on the adaptive process and thus affects the resulting mental health outcome. The size of the arrow is reflective of its disproportional affect. 